
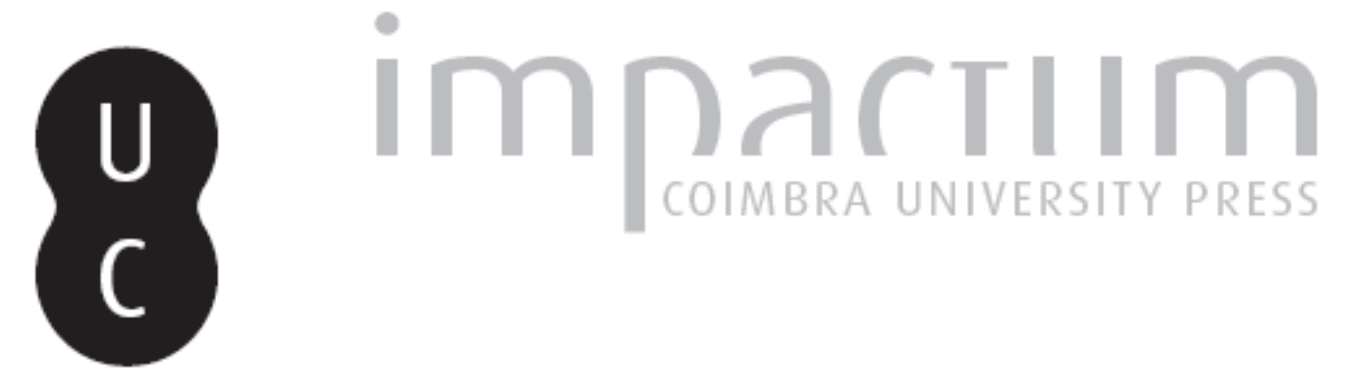

\title{
Form and Architecture
}

\section{Autor(es): $\quad$ Duarte, José P.}

Publicado por: Editorial do Departamento de Arquitetura

URL persistente:

URI:http://hdl.handle.net/10316.2/37230

DOI:

DOI:http://dx.doi.org/10.14195/1647-8681_5_2

Accessed : $\quad$ 26-Apr-2023 11:10:02

A navegação consulta e descarregamento dos títulos inseridos nas Bibliotecas Digitais UC Digitalis, UC Pombalina e UC Impactum, pressupõem a aceitação plena e sem reservas dos Termos e Condições de Uso destas Bibliotecas Digitais, disponíveis em https://digitalis.uc.pt/pt-pt/termos.

Conforme exposto nos referidos Termos e Condições de Uso, o descarregamento de títulos de acesso restrito requer uma licença válida de autorização devendo o utilizador aceder ao(s) documento(s) a partir de um endereço de IP da instituição detentora da supramencionada licença.

Ao utilizador é apenas permitido o descarregamento para uso pessoal, pelo que o emprego do(s) título(s) descarregado(s) para outro fim, designadamente comercial, carece de autorização do respetivo autor ou editor da obra.

Na medida em que todas as obras da UC Digitalis se encontram protegidas pelo Código do Direito de Autor e Direitos Conexos e demais legislação aplicável, toda a cópia, parcial ou total, deste documento, nos casos em que é legalmente admitida, deverá conter ou fazer-se acompanhar por este aviso. 


$$
\text { José P. Duarte }
$$

Form and Architecture 
This section aims to shed new light on Alberti's impact on Portuguese Classical Architecture through the use of innovative methodologies and new technologies. It describes research developed with the goal of studying his famous architectural treatise and the buildings he designed with the support of computational systems, hoping to expand our knowledge of Albertian architectural thinking and Renaissance culture, in general.

It shows recent developments, some from the Digital Alberti Project, using digital technologies applied to architecture, such as generative design systems, digital fabrication, and human-computer interaction.

Generative design systems enable designers to create design languages through the manipulation of shape rules. Instead of generating single solutions, design languages empower designers by allowing them to generate multiple solutions following pre-defined rules or to redefine the rules themselves. Generative design includes approaches like shape grammars, procedural modeling, and parametric modeling.

Digital fabrication technologies enable fast and automated production of physical objects directly from a three-dimensional digital model, which might result from a generative design system. Digital fabrication technologies emerged from rapid prototyping techniques used to test designs solutions, but advances in the state of the art rendered them suitable for manufacturing final products. Digital fabrication includes techniques such as 3D printing, laser cutting, and CNC milling.

Human-computer interaction technologies enable a smoother communication between the users and digital media devices, from consumer products like phones, tablets and televisions, to experimental prototypes such as stereoscopic tabletops or virtual reality head mounted displays, taking advantage of technological advancements like gesture recognition, touchsensitive surfaces, towards good user-centered design of digital experiences.

In this context, Quaresma, Krüger and Duarte's De re aedificatoria column systematization shape grammar, presents the translation of Alberti's text describing how to design the column system into a shape grammar capable to generate the various elements of such system. Figueiredo, Duarte and Krüger's Alberti Digital on Portuguese Architecture: Shape Grammar transformations as a computational framework to determine the influence of Alberti legacy on Portuguese Renaissance churches, describes the translation of Alberti's rules to design churches into to a shape grammar and to which extent it can account for the generation of churches in Portugal of the same period. Fonseca, Mendes, Araújo, Ferreira e Jorge's Interactive Stereoscopic Visualization of Alberti Architectural Models presents a system developed to explore interactively the computer implementation of the two grammars mentioned above in the generation of Albertian designs. Castro e Costa, Duarte, and Krüger's Computational modelling and digital materialization of Alberti's column system: a reflection on results obtained provides a critical reflection on the work developed to model and materialize elements of the column system after the rules set in the treatise. Finally, Morais Trends in Language Formalization in Architecture, presents recent approaches aimed at formalizing the old notion of architectural language. 